\title{
DIGITAL TOPOGRAPHIC MODELLING IN CASE WITH HIGHER FLOOD IN THE MUNICIPALITY OBRENOVAC
}

\author{
ALEKSANDAR VALJAREVIĆ ${ }^{*}$, DRAGICA ŽIVKOVIĆ ${ }^{2}$ \\ ${ }^{1}$ Faculty of Natural Science and Mathematics, University of Priština, Kosovska Mitrovica, Serbia \\ ${ }^{2}$ Faculty of Geography, University of Belgrade, Belgrade, Serbia
}

\begin{abstract}
The town of Obrenovac is situated near the banks of three rivers, the Sava River, the Kolubara River and the Tamnava River. It looks like a modern town, though it has often developed in an unplanned manner. This causes huge problems as it thrives in a rough terrain, without a plan, which the communal infrastructure cannot follow. Today's needs in terms of spatial planning, envisaging projects and keeping track of a different kind of information on space demand that new technologies be applied since they make it possible for procuring efficient and reliable information as well as connecting and interconnecting various sorts of data. Also with advanced numerical GIS data and relief analysis we were successfully calculated consequence of the last big flood in 2014.
\end{abstract}

Keywords: Rivers, Flood, Digital, Modelling, Preventive, GIS.

\section{INTRODUCTION}

The catastrophic floods in May 2014 was producing many damage consequences in the territory of the municipality of Obrenovac. The wild river Kolubara caused a flood to remember. The catastrophic floods which affected Obrenovac were not the first ones for the town to encounter through history. Built not too far away from the banks of the Sava, Kolubara and Tamnava River, Obrenovac seems destined to fight frequent floods. Once time in one-hundred year Obrenovac was hit by the catastrophe flood. Could we have learned a lesson from history and is the town council sufficiently technologically equipped and trained for managing modern technologies? Today's needs in the field of spatial planning, envisaging projects and keeping track of various information demand that new technologies be applied. They make way for efficient and precise information, including the possibility of connecting and interconnecting various sorts of data (www.gis.srbijavode.rs) bearing in mind the fact that the European Union offers a special support to digital society development. Obrenovac is located $28 \mathrm{~km}$ southwest of Belgrade capital of Serbia (Figure 1). It is rightly said to have a long past and a short history. The first settlement to have appeared in its backyard was in the Neolith, cut across by the Tamnava and the Kolubara River, while the rural settlement of Palez was first mentioned in 1717. The name originates from the subterranean swampy terrain that houses were built on. The settlement first developed near the Kolubara River (Radovanović, 1963). After the liberation from the Ottoman rule, it moved west and started being built near the Tamnava River. Because of the floods during high water levels, the town was separated from the river banks although it was near them. The town borders the rivers; the Sava River to the north, the Kolubara River to the west, the Tamnava

\footnotetext{
* Corresponding author: aleksandar.varljarevic@pr.ac.rs
} GEOGRAPHY, GEOSCIENCE AND ASTRONOMY
River to the south and the Velika Bara Canal to the east. The position of 77 metres above sea level, in the Sava and Kolubara alluvial plain, has had an impact on the town being shaped as an inverted letter T (Figure 1).

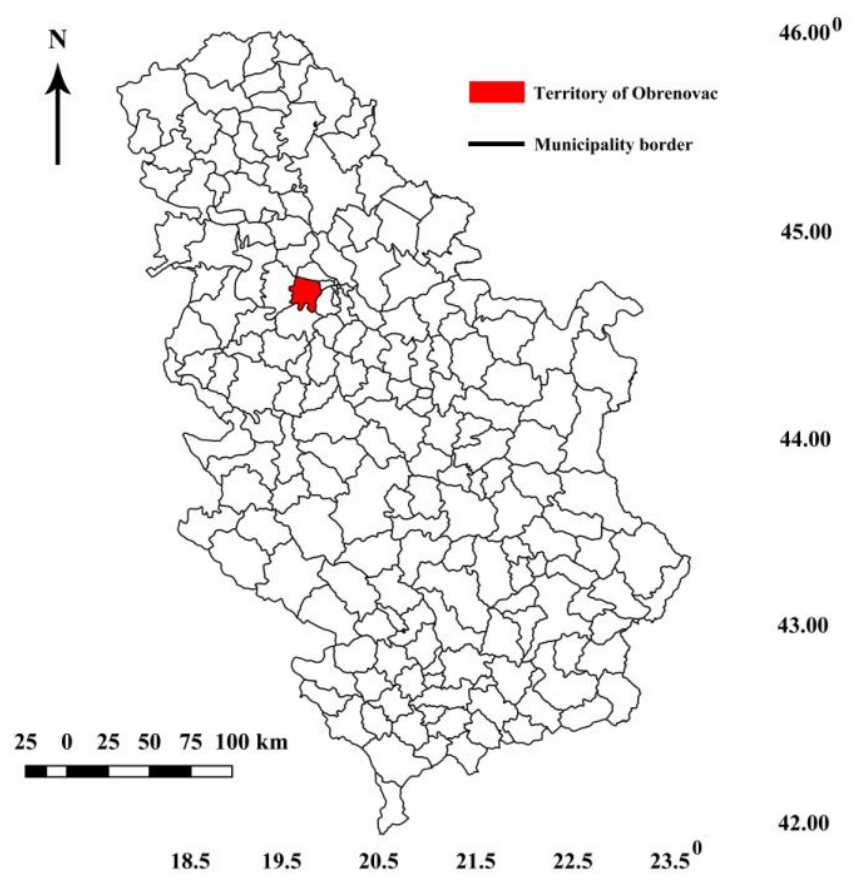

Figure 1. Position of the municipality of Obrenovac.

One leg moves north, near the Obrenovac- Zabrežje outline in the direction of the Sava River as the other gets through the town centre emerging south, at the Kolubara River, following the east-west direction (Živković, 1977). Obrenovačka Posavina is the macro flood area of the Kolubara River over which the Sava is pushed 10 kilometres north of its initial flow below the Posavina section (www.jp.zzs.org.rs.). Basically, all types of soil 
emerged from fluvial erosion or from accumulation. Near Oberenovac, the pronounced Posavina section stretches crosscut in the direction of the lower Kolubara valley. Its bottom fits into the Sava valley bottom and the one of the Srem Ditch. The Posavina section has its origin in a fissure but its appearance of today was created by the crosscut erosion of the Sava. The part of the Posavina Section between Obrenovac and Skela was cut across by wide valleys with terraces, with the bottom that most frequently continues as the Sava terrace with the serpentine and the elaborate Sava and Kolubara river beds. Because of the most recent lowering of the middle parts of the lower Kolubara basin, movement has been intensified, there has been intensified meandering, while the river flows have become dislocated, so that the elaborate Kolubara river beds create some kind of delta. The old Sava meanderings indicate the river's movement over the Sava terrace in the south-north direction (Jovanović, 1956). The process of erosion is ever so present in the territory of Obrenovac Municipality, especially east of the Kolubara River, including the process of eroded material accumulation in the lower flow of the Kolubara River, creating the ideal conditions for flood occurrence with every higher water level (Dragicević, 2002). 3D models make a more flexible view of topography possible while modern technologies account for simulating possible flood scenarios, this way preventing devastating catastrophes one such is the one that hit Obrenovac.

\section{OBTAINING FIELD EXPOSITIONS AND FLT OF OBRENOVAC MUNICIPALITY AREA FILE}

At the beginning of DEM inserting, it is important that the projection to be converted onto the map be determined. The WGS 84 datum and Mercator Projection is taken as the projection file to be transferred onto the map. On determining the projection from the DEM area, the terrain Obrenovac zone borderlines are determined in the altitude range of 70-72, 72-74, $74-76,76-78,78-80,>80 \mathrm{~m}$ (Table 1). Ttherefore, what is obtained among the contour lines in the areas later to be processed in the GIS software called QGIS and SAGA. The data processing is performed in the following way. DEM is inserted with the help of the software function Global Mapper 17. Then what is used is the function File Export Elevation from which the FLT grid format is derived. What is opened is the window in the software Export Slope Direction Values Instead of Evaluations, which is checked in order to determine the desirable altitudes and watershed properties (Figure 2). As FLT file is inserted, the window within DEM is activated (Clarke, 1988).

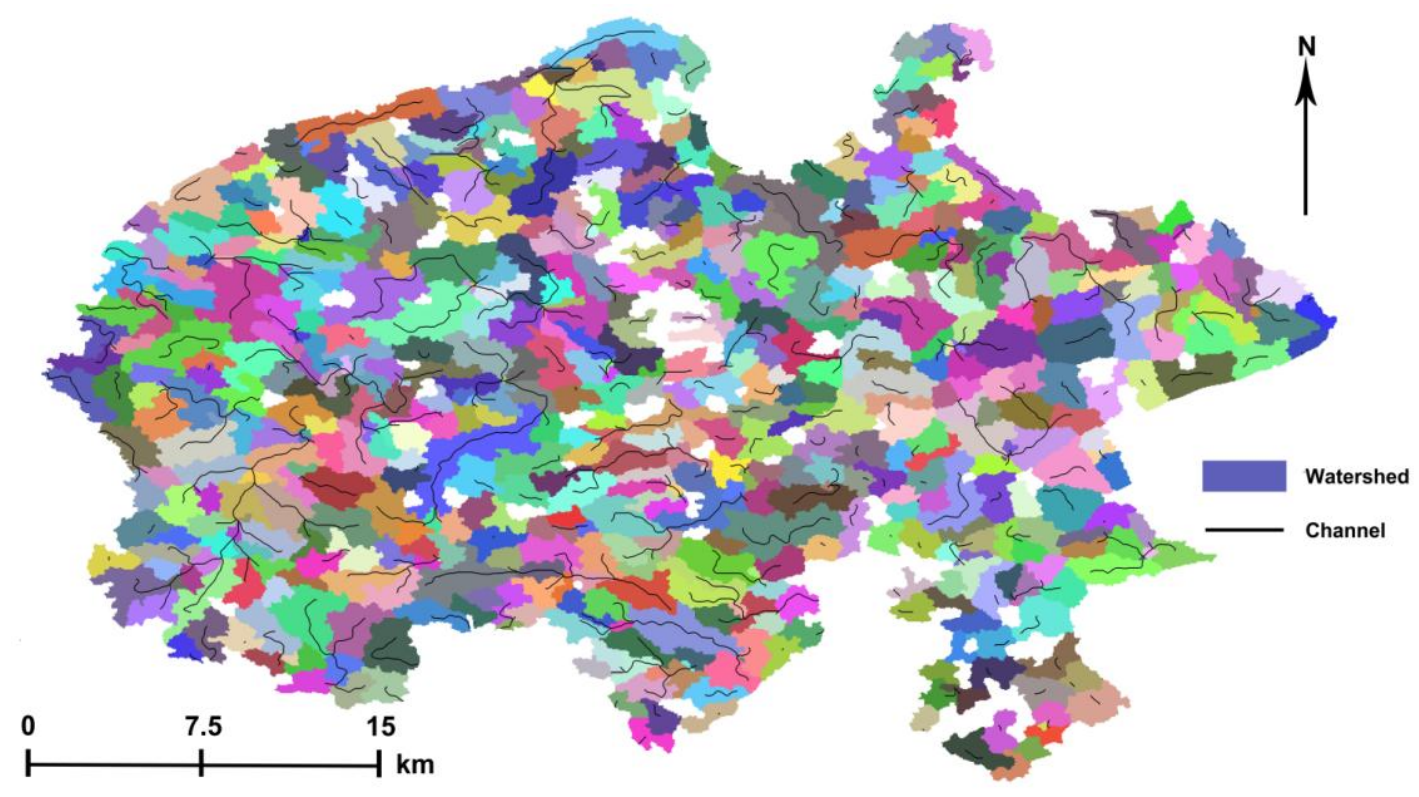

Figure 2. Watershed of the territory of Obrenovac.

\section{DEM PREPARATION AND MAP CONVERSION}

There are numerous ways and methods of data insertion in GIS. One of the methods of determining the contour lines on a particular digital map is the FLT file extrapolation, which is an extension of GRID file. FLT file is suitable as it belongs to a universal extension and as such, it can be read by major GIS software. Another big advantage of FLT is the small size of the outgoing file. The major trait, however, is that DEM can be made out of it, thus creating a 3D model. The example of Obrenovac involves the primary task of making a border on which the grid is to be made. The border that has been taken is the one located on the geo portal http://www.geosrbija.rs/). The border is divided into cadastre sections. On determining the border, what is done next is making the GRID as an FLT format, which later determines the contour lines borders, and by using a special function in the software Global Mapper 17, the areas among these are determined too (Table 1). The scanning has been performed by obtaining altitudes and areas.

What appears to be a great problem of the town of Obrenovac lies in the fact that the Kolubara and Sava banks are at a greater altitude than certain parts of the town. What one can 
see from the table is $10.20 \mathrm{~km}^{2}$ or $24.2 \%$, which is almost a quarter of the town's total area 72 metres high, $35.36 \mathrm{~km}^{2}$ or $83.9 \% 74$ metres high, as the Sava bank is 77 metres (the bank at Zabrezje); the Kolubara bank is 76 metres, that is near the Sava confluence and the altitude at the black point on the road to Sabacbetween Stocnjak and Rvat is $1 \mathrm{~m}$. The lowest point of Obrenovac is at 73 metres above sea level, in the space called Plošće and inside the wide Sava meander, which changes its course near the vicinity of the village of Zabrezje and flooding level was 78 metres above absolute sea level. The digital visualization and simulation of events, for example, what area size would have been flooded if the Sava water level had risen for the altitude assumed, make it possible for envisaging and preventing unfortunate incidents.

Table 1. Area of contour belts of Obrenovac and its properties.

\begin{tabular}{|c|c|c|}
\hline Altitude $\mathbf{~ m}$ & Area $_{\mathbf{~ k m}^{\mathbf{2}}}$ & $\mathbf{\%}$ \\
\hline $70-72$ & 10.20 & 24.193 \\
\hline $72-74$ & 25.16 & 59.677 \\
\hline $74-76$ & 2.62 & 6.214 \\
\hline $76-78$ & 1.90 & 4.509 \\
\hline $78-80$ & 1.84 & 4.364 \\
\hline$>80$ & 0.44 & 1.043 \\
\hline$\sum$ & 42.16 & 100.000 \\
\hline
\end{tabular}

\section{MULTI-CRITERIA GIS ANALYSIS}

Geographic Information System and environmental modelling were applied in hazard investigation. All geospatial data can be used for mapping and modelling of the flood waves on the territory of the Municipality Obrenovac (Valjarević et al., 2018; Valjarević at al., 2017). In this research we used numerical and GIS methods. GIS software's used belongs to open-source software's this software's are QGIS and SAGA. GIS analysis in combination with numerical methods are very powerful tool for calculating flood effects. The process of DEM and basic relief analysis in an area provides letter manipulation in GIS software's. Although, there are a many other methods, but priority is given to 3D modelling and watershed analysis (Figure 2). These methods include numerical autocorrelation and statistical relationship between points into 3D space (Malczewski, 2004; Pew \& Larsen, 2001: Patterson \& HoalstPullen, 2011; Valjarević, 2016). Both, GIS numerical analysis and spatial algorithms can be successfully can implemented in open-source GIS software QGIS. Using GIS software, we cropped territory of municipality Obrenovac after process of digitization. In this way we are manipulating with the vector data. Vector data after GIS total analysis we exported trough tool in one more software called Global Mapper 17. Global Mapper 17 has excellent advantages, especially in 3D analysing and representing (Figure 3). (Valjarević et al., 2015; Patterson \&
Hoalst-Pullen, 2009). We monitored territory of Obrenovac for seven days.

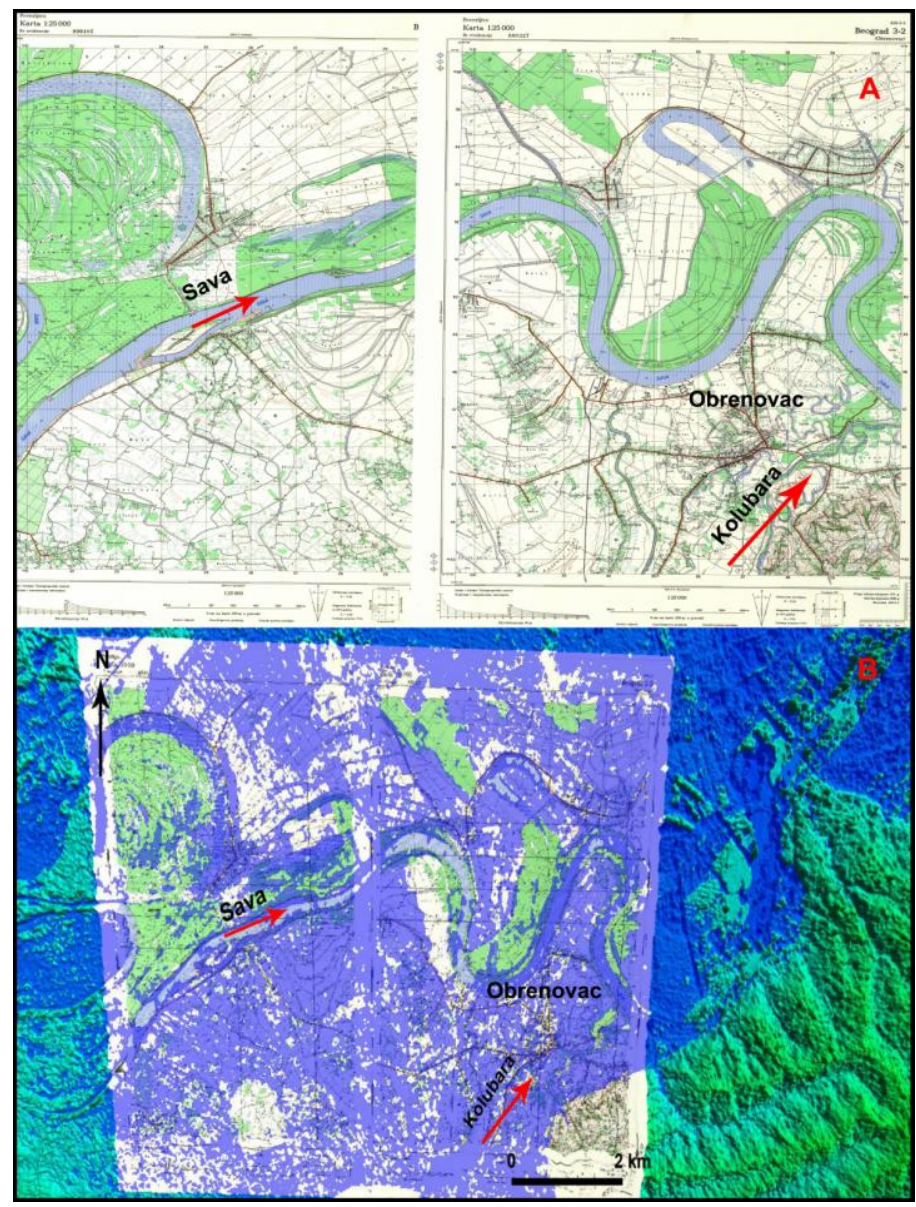

Figure 3. The high volume of wave on May 2014, with flooded areas. A- Situation before May 2014, B-situation in a day with highest wave. High point of Obrenovac is $76.2 \mathrm{~m}$ and after flood in May 2014 was $80.2 \mathrm{~m}$.

\section{ADVANCED GIS AND NUMERICAL METHODS}

Advanced Geographical Information system in combination with remote sensing techniques gave satisfactory results. By applying advanced GIS methodology and numerical methods we analysed flood wave in the territory of Obrenovac. GIS analysis established belts into six values (see Table 1). The special algorithms which situated in the interface of Global Mapper software rendered and vectorised all data of volume of waves. The data of waves are downloaded from the official web page of the Meteorological service of the Republic of Serbia (http://www.hidmet.gov.rs/). But with the help of pairs of two sofwares Global Mapper and SAGA with techniques of Semiautomated and Full-automated kriging we were estimated volume of water in total. The process of vectorisation follows the process of pixelisation. The process of scattered pixels in an area provides later manipulation in GIS software Global Mapper and SAGA for obtaining density and the number of trees. Although there are a few other methods, priority is given to ordinary 
kriging and global kriging methods. These methods include autocorrelation or the statistical relationship among the measured points and are very flexible in the presentation of forest distribution and density (Jankowski et al., 2001).

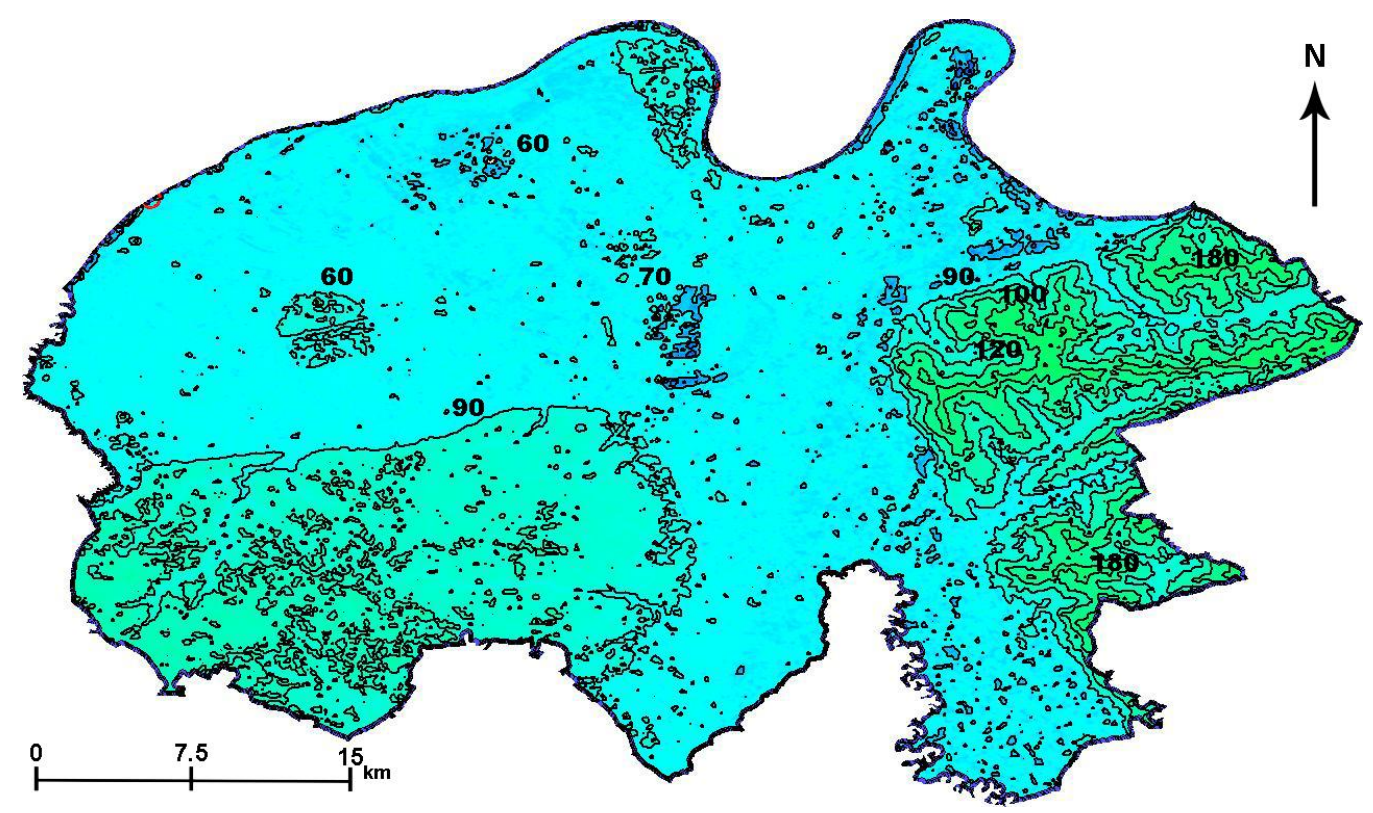

Figure 4. The elevation maps of the Municipality of Obrenovac with proposed contours lines.

\section{RESULTS}

By applying advanced GIS techniques and numerical data, we analyzed the condition of land belts in the municipality Obrenovac after the big flood in 2014 (Valjarević, 2016). With help of official meteorological and cadaster data, we found precise way to establish effects of the hazardous flood. According to GIS numerical and 3D analysis, we calculated area and volume of the flood in the territory of Obrenovac. The municipality of Obrenovac belong to the city of Belgrade and included such as city territory. The area of Obrenovac is $441 \mathrm{~km}^{2}$ after big flood territory covered by water was $78 \%$. But, a territory of a central core of Obrenovac were $99 \%$, as well only $1 \%$ were without food. Reason for that is in the relief properties. West part of the municipality has higher altitudes for almost 10 $\mathrm{m}$, and also distance from river Kolubara is $11 \mathrm{~km}$. $12 \%$ of nonflooded areas situated in the north-west. When we talk about the volume of waves we have next results. First belt between 70-72 m was covered $12 \%$, second belt $72-74 \mathrm{~m}$ was covered $20 \%, 74-$ $76 \mathrm{~m}$ or third belt was covered $31 \%$, third belt between $76-78 \mathrm{~m}$ was covered by $15 \%$ of water, fifth belt $78-80 \mathrm{~m}$, was covered by $20 \%$, finally sixth belt or altitudes higher than $80 \mathrm{~m}$, was covered $2 \%$ of the territory. Also we calculated average and maximum wave of Kolubara and Sava rivers. Average wave of Kolubara river was $2.2 \mathrm{~m}$, and maximum river was 3.7. On the river Sava average river was 3.1 and maximum wave was 4.5. Because terrain as well relief is lower near mouth of Kolubara river, north-east part of Obrenovac was destroyed more. The total volume of water was $17,856,345,455 \mathrm{~m}^{3}$. Also, because of Obrenovac municipality terrain the central territory shows altitudes between 60 and 90 meters, as well west and central part of the municipality lower than eastern and northern parts. After big floods the central part of the municipality is always at risk (see Figure 4; Table 1).

\section{CONCLUSION}

Today's needs in terms of spatial planning, envisaging projects and managing different sorts of information, result in obtaining efficient and reliable information, along with the possibility of connecting and interconnecting various sorts of data. New technology application demands concrete investment and a continual professional engagement, which would make it possible for experts to be used in critical situations and by which human lives would be saved along with the material welfare. By combining topographic and relief maps with 3D terrain models, it is possible to simulate events in space, envision their manifestations and in this light diminish the bad effects. Also with the help of advanced numerical methods results could be more effective. Next step must be in creation database of Obrenovac, in this database it would be necessary to input all vector and hazardous data for better management against future floods. The data updated would be used in the field of water management, agriculture, forestry, environment protection etc.

\section{ACKNOWLEGMENTS}

The authors are very grateful to the municipality of Obrenovac for providing data, as well as to the Serbian Ministry of Education and Science that supported this work within the projects No. III 044006 and No.176008 


\section{REFERENCES}

Clarke, K. C. 1988. Scale-Based Simulation of Topographic Relief. The American Cartographer, 15(2), pp. 173-181. doi:10.1559/152304088783887107

Dragićević, S. 2002. Bilans nanosa u slivu Kolubare. Beograd: Univerzitet u Beogradu - Geografski fakultet, pp. 52-53.

Jovanović, B. 1956. Reljef sliva Kolubare, Prilog poznavanju razvitka polifaznog i poligenetskog reljefa sliva.Beograd: SANU. Poseba izdanja, knjiga CCLXIII.

Malczewski, J. 2004. GIS-based land-use suitability analysis: a critical overview. Progress in Planning, 62(1), pp. 3-65. doi:10.1016/j.progress.2003.09.002

Patterson, M. W., \& Hoalst-Pullen, N. 2009. Local Government Use of GIS in Comprehensive Planning. In J. D. Gatrell \& R. R. Jensen Eds., Planning and Socioeconomic Applications. Geotechnologies and the environment.Dordrecht: Springer Nature America, Inc., pp. 205-220. doi:10.1007/978-1-40209642-6_13

Patterson, M. W., \& Hoalst-Pullen, N. 2011. Dynamic equifinality: The case of south-central Chile's evolving forest landscape. Applied Geography,31(2), pp. 641-649. doi:10.1016/j.apgeog.2010.12.004

Pew, K., \& Larsen, C. 2001. GIS analysis of spatial and temporal patterns of human-caused wildfires in the temperate rain forest of Vancouver Island, Canada. Forest Ecology and
Management, 140(1), pp. 1-18. doi:10.1016/s03781127(00)00271-1

Radovanović, V. 1963. Obrenovac i okolina, Mografija mesta. Beograd: Opština Obrenovac.

Valjarević, A., Djekić, T., Stevanović, V., Ivanović, R., \& Jandziković, B. 2018. GIS numerical and remote sensing analyses of forest changes in the Toplica region for the period of 1953-2013. Applied Geography, 92, pp. 131-139. doi:10.1016/j.apgeog.2018.01.016

Valjarević, A., Srećković-Batoćanin, D., Valjarević, D., \& Matović, V. 2018. A GIS-based method for analysis of a better utilization of thermal-mineral springs in the municipality of Kursumlija (Serbia). Renewable and Sustainable Energy Reviews, 92, pp. 948-957. doi:10.1016/j.rser.2018.05.005

Valjarević, A., Srećković-Batoćanin, D., Živković, D., \& Perić, M., 2015. GIS analysis of dissipation time of landscape in the Devil's city. Acta Montanistica Slovaca, 20(2), pp.148-155.

Valjarević, A., Živković, D. 2016. GIS \& Sattelite detection of forest belt in Prokuplje municipality". Techical Gazette, 23(4), pp. 969-972 doi:10.17559/TV-20140222204458.

Valjarević, A. 2016. GIS modelling of solar potential in Toplica region. The University Thought - Publication in Natural Sciences, 6(1), pp. 44-48. doi:10.5937/univtho6-10739

Živković, D. 1977. Obrenovac-satelitsko naselje Beograda. Zbornik radova Geografskog instituta PMF, Beograd, sv. XXIV. 